\title{
Tips for online learning
}

Learning online is a new experience for many of us. We will be required to approach our learning differently. We may be unsure of expectations and how to go about things. Suddenly we have unstructured time and may not know how to continue with our studies. We suggest that you follow your regular time table to access your lectures, tasks and assignments from the RUconnected site for each course at the set times. This will help to structure your days and keep you from falling behind. However, we can try to take some steps to ensure that we are able to learn online with success. Here are 10 tips to stay focused and successful during this transition to online learning.

\begin{tabular}{|l|l|}
\hline $\begin{array}{l}\text { Tip 1: Download the } \\
\text { RUconnected App }\end{array}$ & $\begin{array}{l}\text { Download the RUconnected app to keep in touch with fellow } \\
\text { students and lecturers. It will allow you to stay up to date with your } \\
\text { coursework and what is expected of you. }\end{array}$ \\
\hline $\begin{array}{l}\text { Tip 2: Consider your } \\
\text { study space }\end{array}$ & $\begin{array}{l}\text { Pick a regular spot where you feel comfortable to study and if } \\
\text { possible, get into the habit of studying there. If you are studying in } \\
\text { spaces shared with others, notify them. If you are able to limit } \\
\text { distractions in your space, do so. Try to avoid multitasking while } \\
\text { you are studying. }\end{array}$ \\
\hline Tip 3: Keep a schedule & $\begin{array}{l}\text { Your lecturer will be sharing online learning materials with you. Try } \\
\text { to use the time when you would have gone to class to engage with } \\
\text { these. Get a few peers to keep the schedule with you. In that way, } \\
\text { you can keep each other accountable and you can ask each other } \\
\text { questions if necessary. }\end{array}$ \\
\hline Tip 4: Take notes & $\begin{array}{l}\text { Re-watching videos, re-listening to podcasts and having } \\
\text { PowerPoint slides available online doesn't mean you shouldn't take } \\
\text { notes. Otherwise, you may be re-watching, re-listening or } \\
\text { re-reading a lot. This is not a very effective learning technique. } \\
\text { Making hand-written notes will help you understand the material } \\
\text { better and will also give you a break from the technology. Pause } \\
\text { recordings and rewind when necessary. }\end{array}$ \\
\hline
\end{tabular}

This resource is licensed under a CC BY 4.0 International license. Attribution: Centre for Higher Education Research, Teaching and Learning (CHERTL), Rhodes University, Makhanda (Grahamstown), SA. 


\begin{tabular}{|c|c|}
\hline $\begin{array}{l}\text { Tip 5: Check your emails } \\
\text { and announcements } \\
\text { regularly }\end{array}$ & $\begin{array}{l}\text { Checking your email and course announcements are even more } \\
\text { important when learning online. It is the main way that your lecturer } \\
\text { will communicate with you. Try to check it daily. }\end{array}$ \\
\hline $\begin{array}{l}\text { Tip 6: Communicate with } \\
\text { your lecturers when } \\
\text { necessary }\end{array}$ & $\begin{array}{l}\text { In a face-to-face class, your lecturer is in front of you and can } \\
\text { gauge understanding. This doesn't happen in online teaching. It is } \\
\text { therefore important for you to contact your lecturer via their } \\
\text { preferred communication channels if you do not understand } \\
\text { something. }\end{array}$ \\
\hline $\begin{array}{l}\text { Tip 7: Stay connected } \\
\text { with classmates }\end{array}$ & $\begin{array}{l}\text { Keep in touch with classmates using chat or discussion forums on } \\
\text { RUconnected or other forms of contact. Let's help and support } \\
\text { each other during this time. }\end{array}$ \\
\hline $\begin{array}{l}\text { Tip 8: Be prepared to } \\
\text { learn online, offline }\end{array}$ & $\begin{array}{l}\text { Plan to learn offline. Use your time well when you have a reliable } \\
\text { internet connection. Download or save learning material to work } \\
\text { through when you are offline. You can also save content on the } \\
\text { RUconnected app to learn offline. }\end{array}$ \\
\hline $\begin{array}{l}\text { Tip 9: Be flexible and } \\
\text { considerate }\end{array}$ & $\begin{array}{l}\text { Learning online during this time is not ideal for anyone. Be } \\
\text { considerate towards fellow classmates and your lecturers as they } \\
\text { deal with an evolving situation. Be prepared to be flexible. Keep in } \\
\text { mind that your lecturers may be getting lots of emails, so identify } \\
\text { yourself clearly in your communications, provide your course code, } \\
\text { and be patient. }\end{array}$ \\
\hline Tip 10: Ask for help & $\begin{array}{l}\text { It is understandable to feel confused switching to online learning } \\
\text { midway through the semester. Don't be afraid to ask for help. Take } \\
\text { advantage of existing support, suggested communication channels } \\
\text { and online office hours provided by your lecturers. }\end{array}$ \\
\hline
\end{tabular}

This resource is licensed under a CC BY 4.0 International license. Attribution: Centre for Higher Education Research, Teaching and Learning (CHERTL), Rhodes University, Makhanda (Grahamstown), SA. 